\title{
Distribution of polycyclic aromatic hydrocarbons (PAHs) in sediment from Muar river and Pulau Merambong, Peninsular Malaysia
}

\begin{abstract}
Previous studies indicated that with increasing industrialization and urbanization, pollution problems have become more significant in Malaysia. West coast of Malaysia is more populated and urbanized than the east and therefore more susceptible to various pollutants. Surface sediment samples were collected from Pulau Merambong and Muar river, Peninsular Malaysia during May 2013 where 16 USEPA Priority Pollutants PAHs were analyzed using gas chromatography-mass spectrometry. Total PAHs in the sediments for Muar river ranged from 15.5 to $165.7 \mathrm{ng} / \mathrm{g} \mathrm{dw}$ whereas the total PAHs for Pulau Merambong ranged from 38.6 to $122.8 \mathrm{ng} / \mathrm{g} \mathrm{dw}$. Due to rapid urbanization and motorization, Muar river showed an increasing trend of PAHs concentrations when compared to a study conducted about a decade ago. Pulau Merambong shows relatively lower PAHs concentrations as compared to other locations in Peninsular Malaysia. However, there is no previous data in Pulau Merambong to evaluate the trend in the petroleum hydrocarbons distribution and concentrations. In general, this study revealed that the lowest concentrations were detected in downstream of the Muar and Pulau Meranbong, respectively. This study also found abundance of high molecular weight (HMW) PAHs as compared to low molecular weight (LMW) PAHs suggesting predominance of pyrogenic PAH sources via atmospheric and long-range input. The ratio of LMW PAHs to HMW PAHs (LMW/HMW) were in the range of 0.0510 .33 indicating pyrogenic input and this is consistent with other diagnostic ratios.
\end{abstract}

Keyword: PAHs; Malaysia; Sediment; Source identification; Pollution 